\title{
AS DEMOLIÇÕES DE PARIS: A MODERNIDADE EM "ROCAMBOLE” (1857-1870)
}

\author{
The demolitions of Paris: Modernity in Rocambole \\ (1857-1870)
}

\author{
Máira de Souza Nunes*
}

\begin{abstract}
RESUMO
Com base na leitura do romance de folhetim Rocambole, o presente artigo pretende analisar as transformações da cidade de Paris durante o II Império de Napoleão III, investigando as representações do processo civilizador oitocentista, da experiência burguesa, bem como as relações entre a cidade e o enredo da obra. Pensar, a partir da narrativa folhetinesca, de que maneira a experiência urbana foi vivenciada na Paris moderna, cenário das aventuras de Rocambole. Representada pelo autor Ponson du Terrail como a "babilônia moderna", a capital francesa foi ela mesma um personagem importante da trama. A vida urbana representada pelo autor compreende a circulação pelas paisagens parisienses tanto dos bairros ricos e nobres, quanto dos subúrbios assolados pela miséria. $\mathrm{O}$ conceito de civilização que norteia esta pesquisa baseia-se na ideia de que o indivíduo moldou seu comportamento em resposta às demandas criadas pelas transformações que marcaram o século XIX. As transformações que caracterizaram o período, relacionadas à ideia de progresso, resultaram na construção do conceito de modernidade enquanto desenvolvimento do pensamento burguês nas esferas pública e privada. Porém, o preço desse enriquecimento da sensibilidade pessoal vivenciado a partir da cidade significava o afastamento dos confortos psicológicos da tradição e de qualquer sentido de participação em um todo social integrado. Os personagens de Rocambole vivenciam todas essas experiências modernas de maneira distinta, e representam as contradições presentes na sociedade e na cidade de Paris.
\end{abstract}

Palavras-chave: Rocambole; Paris; Civilização.

* Professora do Centro Universitário Internacional Uninter, mestra em História (UERJ), doutoranda em Comunicação e Linguagens (UTP). Intgrante do grupo de pesquisa JorXXI (UTP). 


\begin{abstract}
Based on the reading of the serial novel Rocambole, this article analyzes the transformations of the city of Paris during the II Empire of Napoleon III, investigating the representations of the nineteenth century civilizing process, the bourgeois experience as well as the relationship between the city and the history of the novel. The research intends to think, from the feuilletonistic narrative, how the urban experience has been experienced in modern Paris. The city of Paris was the center stage for the adventures of Rocambole. Posed by Ponson du Terrail as "Modern Babylon", the French capital was itself an important character in the plot. The urban life represented by the author includes the circulation in Parisian landscapes from rich and noble neighborhoods, and also the suburbs plagued by poverty. The concept of civilization that guides this research is based on the idea that individuals have shaped their behavior in response to demands created by the transformations that marked the nineteenth century. The transformations that characterized the period, related to the idea of progress, resulted in the construction of the concept of modernity as a development of bourgeois thought in the public and private spheres. But the price of this enrichment of the personal sensitivity experienced from living in the city meant the removal of the psychological comforts of tradition and of any sense of participation in an integrated society. The Rocambole characters go through all these modern experiences in different ways, and represent the contradictions present in society and in the city of Paris.
\end{abstract}

Keywords: Rocambole; Paris; Civilization.

Rocambole era um mero garoto de Paris que após fugir da correcional, aos dezesseis anos, foi "adotado" por uma taverneira e passou a ajudá-la a administrar os negócios, divertindo-se em roubar os clientes. Possuía uma astúcia fora do comum e um senso de oportunidade que lhe garantiam escapar das situações mais perigosas. Interessado em um bom pagamento, associou-se ao Visconde Andréia, fidalgo deserdado que desejava vingar-se do meio-irmão, a quem considerava responsável pela sua ruína. Sob sua orientação, Rocambole desenvolveu modos de conduta necessários para frequentar a alta sociedade e ambos reuniram uma organização secreta que buscava, por meio de uma rede de intrigas e manipulações, alcançar o benefício financeiro e social. Após falhar em suas empreitadas, Rocambole foi vítima de uma vingança que o deixou desfigurado, mas proporcionou a circunstância da sua 
redenção. Arrependido de seus crimes voltou à sociedade parisiense decidido a utilizar suas habilidades para o bem, ao prover o auxílio necessário às vítimas de um sistema social opressor e corrupto, regido pelo poder monetário. Conhecedor dos vícios que assolavam a sociedade moderna, utilizava as mesmas armas de sua antiga vida criminosa - dissimulação e engodo - para combater o crime e a vilania.

Assim surgiu o grande herói literário do II Império francês, justiceiro folhetinesco que reuniu uma legião de fãs, responsáveis pela extensão de suas aventuras durante 13 anos. Figura constante nos jornais, o personagem foi alvo de caricaturas e sátiras devido não apenas às suas "aventuras sem fim", mas principalmente ao seu principal talento: a trapaça. O sucesso da série intrigou os críticos, inconformados com o fato de um romance de folhetim alcançar tamanha repercussão e transformar o personagem, um jovem bandido, em um herói popular.

O conjunto de aventuras de Rocambole, reunidas sob o nome Les Drames de Paris $^{1}$, foi escrito por Ponson du Terrail e publicado nos jornais parisienses durante os anos de 1857 a $1870^{2}$. A publicação coincide com o império de Napoleão III, período em que a França passou por um processo de grande desenvolvimento caracterizado pela ascensão da burguesia ao poder, o avanço do capitalismo, mudanças nas esferas pública e privada. Esse processo foi resultado das transformações ocorridas a partir da grande Revolução de 1789 e gerou uma série de contradições que estiveram presentes durante todo o século e marcaram a sociedade do II Império.

Com base na leitura do romance de folhetim Rocambole, o presente artigo pretende analisar as mudanças na vida parisiense

1 As aventuras de Rocambole compreendem 13 episódios principais, reunidos posteriormente em volumes que compõem a série Os Dramas de Paris. As condições de publicação da obra, inicialmente em folhetins diários e depois reunida em volumes, dificultam estabelecer um número preciso de volumes, pois estes variam de acordo com a edição.

2 Para esta pesquisa, foi utilizada a edição brasileira da Companhia Brasil Editora, de 1946, sob o título de Rocambole e composta por 12 episódios reunidos em oito volumes: TERRAIL, Ponson du. Rocambole. São Paulo: Companhia Brasil Editora, 1946. (Coleção Particular). Volumes: 1. A Herança Misteriosa; 2. O Clube dos Valetes de Copas; 3. As Proezas de Rocambole; 4. A Desforra de Baccarat / Os Cavaleiros do Luar / O Testamento do Grão de Sal; 5. A Ressurreição de Rocambole; 6. A Última Palavra de Rocambole; 7. As Misérias de Londres / As Demolições de Paris; 8. A Corda do Enforcado / As Maravilhas do Homem Pardo. 
durante o II Império de Napoleão III, investigando as representações do processo civilizador oitocentista, da experiência burguesa, bem como as relações entre a cidade e o enredo da obra. Pensar, a partir da narrativa folhetinesca, de que maneira a experiência urbana foi vivenciada na Paris moderna.

\section{O Folhetim e a Civilização do Século XIX}

Criado na França, no início do século XIX, o folhetim designava um espaço geográfico no jornal, o rodapé, cuja finalidade era atrair o público leitor e suprir, pela via do entretenimento, o vazio deixado pela censura napoleônica. ${ }^{3} \mathrm{O}$ processo de alfabetização das massas, realizado ao longo do século XIX, resultou em um número crescente de novos leitores interessados especialmente em periódicos e ficção barata.

Um dos fatores relacionados à ampliação do público leitor, durante todo o século XIX, foi o barateamento do preço dos impressos, responsável pelo aumento da publicação de jornais e da tiragem de livros. Um conjunto de variáveis tornou essa expansão possível. As inovações técnicas no ramo tipográfico favoreceram o processo de fabricação e a introdução do uso de prensas mais modernas permitiu o aumento da produtividade dos jornais. A ampliação dos espaços de leitura foi favorecida pelo gabinete de leitura, surgido durante a Restauração, que oferecia o aluguel de livros e jornais mediante uma assinatura a preço acessível. As formas de divulgação também foram melhoradas através da 
literatura de colportage, composta por volumes baratos vendidos por mascates. ${ }^{4}$

A proposta inicial era que fosse um espaço para a publicação de variedades e foi durante a década de 1830 que os jornais franceses passaram a publicar obras literárias de ficção, divididas em fragmentos diários. Marlise Meyer ${ }^{5}$ classifica a produção folhetinesca oitocentista em três momentos: 1836-1850: folhetim romântico ou democrático (Alexandre Dumas, Eugène Sue); 1851-1871: Rocambole ou a "Ilíada de realejo" (Ponson du Terrail); 1871-1914: os romances dos "dramas da vida" (Xavier de Montépin, Émile Zola). Em sua análise, a autora investiga os modos de escrita do folhetim, estabelecendo um comparativo entre os principais autores, e destaca a importância da obra de Ponson du Terrail no mercado folhetinesco.

Da mesma forma, a relação entre o folhetim e a sociedade foi estudada por Roger Bellet, em sua análise sobre a imprensa do Segundo Império. ${ }^{6} \mathrm{O}$ autor pesquisou os registros de época sobre jornais, editores, escritores e leitores e discute a ação jornalística e a difusão do romance de folhetim no governo de Napoleão III. Durante o regime imperial, a imprensa viveu um período de expansão, regulada por uma legislação restritiva que limitou principalmente o viés político dos jornais. O esvaziamento das discussões sobre a atuação do governo abriu espaço para o fortalecimento do folhetim, que passou a ser recebido pelo público leitor como uma possibilidade de escape à realidade. Nesse sentido, o autor preocupou-se em investigar a relação entre o romance de folhetim e a realidade social e quais os limites da influência recíproca entre ambos, ressaltando que a realidade do II Império não deixou de ser folhetinesca. ${ }^{7}$

Um dos caminhos de análise sobre as transformações resultantes do desenvolvimento oitocentista é a discussão do conceito

4 NUNES, Máira de Souza. Modernidade e civilização na imprensa francesa oitocentista: o romance-folhetim. In: Tuiuti: Ciência e Cultura, n. 48, p. 33-49, Curitiba, 2014.

5 MEYER, op. cit.

6 BELLET, Roger. Presse et journalisme sous le Second Empire. Paris: Armand Colin, 1967.

7 BELLET, Roger, op. cit., p. 203. 
de civilização e do decorrente processo civilizador oitocentista. Para Norbert Elias ${ }^{8}$, o conceito de civilização representa a expressão da consciência que o ocidente tem de si mesmo. Essa consciência decorre da mudança estrutural ocorrida na sociedade ocidental, a qual procura descrever o que representa seu caráter especial, aquilo de que se orgulha, sua visão de mundo. A partir dessa consciência, o processo civilizador resulta na mudança de comportamento do indivíduo com relação aos seus controles emocionais, um caminho de aprendizado de comportamento a partir das mudanças no que a sociedade exige e proíbe. Dessa forma, estruturas de personalidade e estruturas sociais sofrem uma evolução inter-relacionada, levando à necessidade de adaptação por parte do indivíduo e do mundo a sua volta, para tornar possível a existência no mundo moderno. ${ }^{9}$

O termo civilização foi formulado no século XIX e referia-se a um conceito pré-existente - civilidade - significando "abrandamento dos costumes, educação dos espíritos, desenvolvimento da polidez, cultura das artes e das ciências, crescimento do comércio e da indústria, aquisição das comodidades materiais e do luxo." 10 No século XIX, a ideia de civilização foi ampliada e além do aperfeiçoamento interior dos indivíduos e o desenvolvimento de suas qualidades afetivas e intelectuais, passou a significar também o crescimento dos recursos e da segurança que correspondem ao gênero de vida das classes sociais abastadas da sociedade industrial moderna. No entanto, essas duas faces, interior e exterior, permanecem contraditórias enquanto "a justiça, a liberdade, a moralidade não acompanham a acumulação dos bens e do desenvolvimento complexo das leis e das instituições públicas." ${ }^{11}$

O conceito de civilização que norteia este artigo baseia-se na ideia de que o indivíduo moldou seu comportamento em resposta às demandas criadas pelas transformações que marcaram o século XIX. Nesse sentido, Sigmund Freud considera que a civilização foi

8 ELIAS, Norbert. O processo civilizador. Rio de Janeiro: Jorge Zahar Ed., 1994. Vol. 1 - Uma história dos costumes.

9 Idem.

10 STAROBINSKI, Jean. As máscaras da civilização: ensaios. São Paulo: Companhia das Letras, 2001, p. 14.

11 Idem, p. 44-45. 
responsável pela infelicidade do ser humano a partir do momento em que a tarefa de evitar o sofrimento colocou a de obter prazer em segundo plano. Em troca de segurança, o sujeito civilizado moderno abriu mão de sua individualidade e de sua liberdade e esse esforço civilizacional representou o sacrifício do "ser feliz" nessa civilização. Assim, as forças externas tolheram a possibilidade de autonomia e nivelaram o indivíduo em uma existência regulada pelo social. ${ }^{12}$

Relacionado à ideia de Freud, de que as sociedades exigem que seus membros sacrifiquem seus desejos para garantirem a sobrevivência comum, Peter Gay ${ }^{13}$ salienta que o desenvolvimento técnico e a fundação de instituições para distribuir os bens essenciais possibilitaram ao indivíduo do século XIX uma espécie de "ataque" ao mundo. Esse ataque foi destinado a reduzir a dor da existência e refere-se à capacidade de ser agressivo e de transformar situações desagradáveis em um impulso mobilizador. Essa agressividade não representa apenas a ideia de violência, mas, principalmente, de transformação. Dessa forma, o século XIX foi uma era de agressão, em que a destruição representou a preparação para a reconstrução, e que marcou as relações do indivíduo em sociedade.

É essa "agressividade" que caracteriza o personagem Rocambole. No romance, seu "ataque" ao mundo revela-se inicialmente como confronto social por meio do banditismo, do qual Rocambole espera extrair dividendos que compensem a sua situação social. Num segundo momento, após seu arrependimento, Rocambole empreende este ataque como forma de justiça social ao fugir da impotência que regula as relações sociais, e estabelece seu próprio padrão de reação à uma sociedade que não possibilita soluções coletivas.

As transformações que caracterizaram o século XIX, relacionadas à ideia de progresso, resultaram na construção do conceito de modernidade enquanto desenvolvimento do pensamento burguês nas esferas pública e privada. Este conceito comumente se refere ao século XIX como o "século moderno". No caso da França e

12 FREUD, Sigmund. O mal-estar na civilização. Rio de Janeiro: Imago, 1997, p. 137.

13 GAY, Peter. $O$ cultivo do ódio: a experiência burguesa: da Rainha Vitória a Freud. São Paulo: Companhia das Letras, 2001. 
da cidade de Paris, particularmente, a modernidade é frequentemente percebida como um fenômeno que transformou radicalmente a cidade e seus habitantes. Walter Benjamin, a partir dos escritos de Charles Baudelaire, nomeou Paris como "a capital do século XIX", devido ao fato de a cidade ter abarcado vários elementos inerentes à modernidade. A partir da reforma urbana realizada durante o II Império, o papel da multidão, do flâneur e de várias personagens urbanas desenvolveu novas formas de sociabilidade e fez com que Paris passasse a ser vista como a "babilônia" do século XIX. ${ }^{14}$

Marshall Bermann considera que a modernidade compreende a transformação urbana decorrente do avanço capitalista e a visão cultural dos indivíduos que vivem esse processo de modernização. Essa experiência da modernidade significa "encontrar-se em um ambiente que promete aventura, poder, alegria, crescimento, autotransformação e transformação das coisas em redor - mas, ao mesmo tempo, ameaça destruir tudo o que temos, tudo o que sabemos, tudo o que somos." 15

Nestes estudos privilegiou-se a análise da ordem da transformação, representada pelo desenvolvimento técnico e sua influência na vida cotidiana, em detrimento da ordem da permanência representada pelo ideal conservador e pelas estruturas sociais tradicionais. O conceito de modernidade foi estabelecido como um rompimento radical com o passado, de tal ordem que torna possível ver o mundo como uma tabula rasa, sobre a qual o novo pode ser inscrito sem referência ao passado. ${ }^{16}$ No entanto, é possível pensar esta sociedade como estando "a meio caminho", entre o velho e o novo, pois as mudanças convivem com a permanência de antigos modos de vida. Dessa forma, a análise do projeto civilizacional do ocidente moderno pressupõe a identificação do caminho percorrido pelo indivíduo desse tempo, em seu aprendizado social do ser moderno. Pensar, a partir da noção de perda de sentido para a

14 BENJAMIN, Walter. Charles Baudelaire um lírico no auge do capitalismo. São Paulo: Editora Brasiliense, 1989, p. 35.

15 BERMANN, Marshall. Tudo o que é sólido desmancha no ar: a aventura da modernidade. São Paulo: Companhia das Letras, 1997, p. 15.

16 HARVEY, David. Paris, capital of modernity. New York: Routledge, 2006, p. 10. 
civilização do século XIX, como esse processo foi vivido e em que acarretou, para o indivíduo e a sociedade, esse aprendizado.

A crença no progresso, resultado do avanço capitalista, trouxe uma crescente racionalização e intelectualização, a certeza de um futuro onde tudo pode ser previsto e dominado. Para Max Weber, esse pensamento representa o mesmo que "despojar de magia o mundo". Este desencantamento do mundo acarretou para a sociedade moderna a construção de uma civilização rica em pensamentos e experiências, mas longe de uma plenitude de vida ${ }^{17}$. Ao capturar apenas o provisório, ante um novo progresso, o indivíduo da vida moderna jamais atinge o grau último de satisfação pessoal, a sensação de missão cumprida. Dessa forma, a perda de sentido característica desse desencantamento demonstra que o avanço científico não acrescenta nenhum valor à existência humana, não apresenta nenhuma resposta às questões do espírito, apenas transforma-se em vertigem, diante de cada nova descoberta.

Sobre a experiência moderna, Carl Schorske ${ }^{18}$ considera que surgiu na França, durante a metade do século XIX, uma nova maneira de pensar e sentir que lentamente estendeu seu domínio sobre a consciência do Ocidente. Esse processo de reavaliação do papel da razão e do sentido da história incluiu a ideia da cidade, "situada para além do Bem e do Mal", a partir da perda da clareza de sentido de seu papel exercido anteriormente (vício ou virtude). Na história da ideia de cidade, como em outros ramos da história, o novo frutifica a partir do velho com mais frequência que o destrói. A questão colocada sobre "o que é a vida moderna?" revelou a cidade em todos os seus aspectos positivos e negativos, como base essencial da existência moderna, a qual deveria ser experimentada em sua plenitude pessoalmente. Porém, o preço desse enriquecimento da sensibilidade pessoal vivenciado a partir da cidade significava o afastamento dos confortos psicológicos da tradição e de qualquer sentido de

17 WEBER, Max. Ciência e Política: duas vocações. São Paulo: Martin Claret, 2005, p. 38

18 SCHORSKE, Carl. A ideia de cidade no pensamento europeu: de Voltaire a Spengler. In: Pensando com a História: indagações na passagem para o modernismo. São Paulo: Companhia das Letras, 2000. 
participação em um todo social integrado. ${ }^{19}$ Os personagens de Rocambole vivenciam todas essas experiências modernas de maneira distinta, e representam as contradições presentes na sociedade e na cidade de Paris.

\section{Rocambole em Paris}

Paris representou a cidade moderna ${ }^{20}$ não só pelo seu crescimento durante o século XIX, mas também pela maneira como criou espaços para o desenvolvimento de novas formas de sociabilidade e possibilidades de se relacionar com o urbano.

Porque Paris era uma cidade diferente de qualquer outra, ao mesmo tempo uma capital nacional, um foco de atividades e ambições políticas e intelectuais, um centro de manufatura (baseada em métodos de atividade manual que ainda predominavam no continente antes de 1850) e o cenário de uma população de estudantes ampla e extremamente consciente. $^{21}$

Walter Benjamin analisa a cidade de Paris como o cenário de representação do flâneur o curioso indivíduo errante e observador das ruas parisienses:

A rua se torna moradia para o flâneur que, entre as fachadas dos prédios, sente-se em casa tanto quanto o

19 SCHORSKE, op. cit., p. 66.

20 Walter Benjamin considera a Paris do século XIX como o laboratório da cidade moderna.

21 SEIGEL, Jerrold. Paris Boêmia: cultura, política e os limites da vida burguesa. 1830-1930. Porto Alegre: L\&PM, 1992, p. 29. 
burguês entre suas quatro paredes. Para ele, os letreiros esmaltados e brilhantes das firmas são um adorno de parede tão bom ou melhor que a pintura a óleo no salão do burguês; muros são a escrivaninha onde apóia o bloco de apontamentos; bancas de jornais são suas bibliotecas, e os terraços dos cafés, as sacadas de onde, após o trabalho observa o ambiente. ${ }^{22}$

Esta paisagem aberta ao flâneur sofreu sua principal transformação quando o Barão Haussmann, nomeado prefeito de Paris em 1853, iniciou o projeto de reforma da cidade. Um novo espaço urbano, um novo mundo ao qual Eric Hobsbawm classifica como um mundo que não consistia apenas em fábricas, empregados e proletários, ou que tivesse sido transformado repentinamente pelo enorme progresso de seu setor industrial; mas que, juntamente com o trabalho industrial em si, na sua organização característica - além da urbanização - eram certamente as formas mais dramáticas da nova vida. $^{23}$

O desenvolvimento capitalista promoveu a transformação da cidade e da sociedade e criou novas demandas de produção. Os meios de comunicação e de transporte participaram deste desenvolvimento geral. Nesse período, a expansão da imprensa deveu-se à industrialização que atingiu a cidade e o campo: "o jornal vai se inserir cada vez mais na vida cotidiana das populações menos disseminadas e cada vez mais ávidas por conhecer o mundo. Até nas províncias os jornais vivem das cidades." ${ }^{24}$ Deve-se somar a este papel da indústria e das cidades o do público, que cresceu e aumentou as suas exigências. A indústria jornalística, visando ampliar sua tiragem, criou o journal à un sou, o jornal de um tostão. Empresários passaram a construir uma diferenciação de classes entre o público burguês e o público popular.

22 BENJAMIN, op. cit., p. 35.

23 HOBSBAWM, Eric J. A Era do Capital: 1848-1875. Rio de Janeiro: Paz e Terra, 1977 , p. 222

24 MEYER, op. cit., p. 91. 
O II Império representou para a imprensa uma época de grande expansão. $\mathrm{O}$ barateamento do jornal produziu uma diferenciação de público-leitor alvo: cada camada social, seja burguesa ou popular, procurou o jornal mais adequado à sua condição. $O$ jornalismo sofreu a influência da vida material que $o$ cercava, seja financeira ou industrial, com o surgimento de novas prensas e máquinas de imprimir. A imprensa alimentou-se também dos novos espaços de sociabilidade criados na cidade. Segundo Walter Benjamim a atividade dos cafés treinou os redatores no novo ritmo informativo antes mesmo que a sua maquinaria estivesse desenvolvida, tornando o espaço público o principal local de produção.

Assim, a assimilação do literato à sociedade em que se encontrava se consumou no bulevar. Era no bulevar que ele tinha à disposição o primeiro incidente, chiste ou boato. No bulevar, desdobrava os ornamentos de suas relações com colegas e boas-vidas, e estava tão dependente de seus efeitos quanto as coquetes de sua arte de se transvestir. No bulevar, passava suas horas ociosas, exibindo-as às pessoas como parcela de seu horário de trabalho. Portava-se com se tivesse aprendido de Marx que o valor de cada bem é definido pelo tempo de trabalho socialmente necessário para a sua produção. Dessa forma o valor de sua própria força de trabalho adquire alguma coisa próxima ao fantástico em face do dilatado ócio que, aos olhos do público, é necessário para o seu aperfeiçoamento. ${ }^{25}$

Os cafés literários, a imprensa sensacionalista, o telégrafo elétrico, na metrópole do século XIX, eram os sinais de um ritmo cada vez mais acelerado da indústria de informação. Para a literatura, como para o jornalismo, passaram a valer as mesmas condições de 
produção das demais mercadorias: era fabricada em ritmo industrial. ${ }^{26}$ Toda esta expansão do mercado editorial e seu caráter comercial permitiram que o jornal se tornasse a porta de entrada aos jovens escritores interessados em arriscar-se na carreira literária. Porém, esta forma de produção possibilitou a criação de um caráter de mercadoria às obras, em que o autor não tinha mais controle sobre a sua produção.

A confecção do romance estava sujeita à vontade do editor e do público, fazendo com que o autor deixasse de ter poder sobre a sua criação, tendo que responder a uma demanda que o tornava apenas o fabricante de um produto de mercado, sujeito às leis do mesmo.

Muitos estavam convencidos de que a cultura só poderia ser rebaixada com sua entrada no mercado. O mundo do comércio era muito estreito para conter os amplos espaços da imaginação. Seus valores eram utilitários e terrenos, baixando a aspiração da beleza e da exaltação que inspiravam a poesia e a arte. $\mathrm{O}$ artista foi privado do lazer necessário ao desenvolvimento de seus talentos pela necessidade de ganhar o seu pão. Também não lhe foram dadas as oportunidades de criar em grande escala e produzir a obra monumental que havia permitido ao gênio de expressar no passado. ${ }^{27}$

Ao se pensar em história literária deve-se ter como base, no contexto de formação do mercado literário, a literatura em estreita inter-relação com a história da imprensa e da informação, visto que a importância crescente dos jornais em detrimento das revistas representou o início de um novo ritmo de escrever que privilegiava a informação curta e abrupta. Segundo Walter Benjamin, as inovações técnicas introduzidas no jornal na década de 1830 acabaram por definir este novo ritmo de produção que incluíam, como forma de

26 BOLLE, Willie. Fisiognomia da metrópole moderna: representação da história em Walter Benjamin. São Paulo: Editora da Universidade de São Paulo, 1994, p. 77.

27 SEIGEL, op. cit., p. 30. 
atrair novos leitores, a diminuição do preço da assinatura, da inserção cada vez maior de anúncio e do romance-folhetim. Os literatos tiveram que se adaptar aprendendo técnicas de escrever mais rápido, mais diversificado e mais leve, criando o "estilo folhetinesco". O folhetim tornou-se o produto literário mais importante, do ponto de vista do mercado, em torno do qual giravam os demais gêneros; sendo que a análise destes leva à compreensão do imaginário social e da mentalidade presentes na "Grande Cidade". ${ }^{28}$

O rápido e aparentemente caótico crescimento de Paris durante o século XIX tornou a vida urbana difícil de decifrar, decodificar e representar. Muitos dos romancistas do período lutaram para estabelecer os termos da natureza da cidade. Eles registraram muito sobre seu mundo material e os processos sociais que fluíam ao seu redor, exploraram diferentes formas de representar seu mundo e ajudaram a moldar a imaginação popular sobre o que a cidade era e o que deveria ser. Eles decodificaram a cidade e a tornaram legível, fornecendo formas de representar os processos da transformação urbana. ${ }^{29}$

A cidade de Paris foi o palco principal para as aventuras de Rocambole. Representada por Ponson du Terrail como a "babilônia moderna", a capital francesa foi ela mesma um personagem importante da epopeia rocambolesca. A vida urbana representada pelo autor compreende a circulação pelas paisagens parisienses tanto dos bairros ricos e nobres, quanto dos subúrbios assolados pela miséria.

A seus pés o colosso de pedras e de lama, Paris dormia, envolvida na névoa, o seu sono febril e ruidoso.

Perto dali, no tôpo da subida, coroava o teatro da Ópera uma auréola de claridade; os boulevards estavam iluminados com grinaldas de luz e pareciam ligar a Paris brilhante e explêndida da Madalena à Paris sombria do "faubourg" Santo Antonio; a Paris dos ricos e dos pobres à Paris da ociosidade dourada, e a do trabalho árduo.

28 BOLLE, op. cit., p. 78.

29 HARVEY, op. cit., p. 35. 
Mais longe, no horizonte, na margem oposta do Sena, avistava o máscara o Panteon envolvido na neblina da noite, elevando a sua cúpula severa sob a sombria abóbada do céu.

À direita daquele monumento, o austero "faubourg" S. Germain, [...]. À esquerda, e estendendo-se até as ribanceiras lamacentas de Bievre, o miserável "faubourg" S. Marceau, mal alumiado por candieiros colocados a longos intervalos, semelhantes a faróis dispersos em um mar tempestuoso. ${ }^{30}$

Durante o período em que a série foi escrita, 1857-1870, a cidade de Paris passou por uma intensa reforma urbana que transformou as antigas vielas medievais do centro da cidade em grandes boulevards, ampliou a área da cidade a partir da anexação das comunas vizinhas e alterou a estrutura de vida dos cidadãos parisienses. No entanto, os primeiros episódios da série se passam na década de 1840, durante a Monarquia de Julho, período anterior à grande reforma urbana de Napoleão III. Ponson descreve a cidade em detalhes e reaproxima o leitor do universo conhecido e familiar préreforma.

Dezembro desdobrava as nubladas asas sôbre a grande cidade que se estende pelas duas margens do Sena.

Uma chuva fina, penetrante e gelada, saía do nevoeiro que cobria Paris, e molhava as ruas. Os candieiros da iluminação espargiam débil claridade nos becos e ruas estreitas dos bairros populosos.

Era noite, uma noite fria de inverno, e os que passavam nas ruas corriam como espectros, que, demorando-se na terra, e vendo aproximar-se o dia, fugiam para os sepulcros.

Paris parecia deserta àquela hora. Soava lugubremente no espaço a meia noite, nos sinos de todas as igrejas; as praças do mercado, o grande foco do movimento e da

30 TERRAIL, op. cit., vol. 1, p. 27. 
vida popular, dormiam por instantes, esperando os pesados carros dos hortelães.

Recolhera-se a última carruagem do baile, e a primeira carreta de trabalho ainda não começara a rodar. Um silêncio sepulcral reinava nas duas margens do rio e deixava ouvir, com longos intervalos, o passo regular das patrulhas fazendo ronda, ou o uivar de algum cão de guarda dos pátios das velhas casas do Marais.

No cáis de S. Paulo, perto do pôsto da guarda, um homem embrulhado em uma capa caminhava pausadamente, indiferente ao frio e à chuva, e parecendo absorto em profunda meditação.

De vez em quando parava e olhava para o rio lodacento que corria com surdo murmúrio entre as duas margens, ora para o montão de casas velhas que ornam o cáis, e representam ali o último vestígio, um resto arruinado da Paris de Carlos VI e de Luiz XI.

Depois olhava para as negras tôrres de Nossa Senhora, que se destacava sob o céu sombrio, e subindo às nuvens com a sua corôa de nervos. O homem continuava o seu caminho e parecia falar consigo mesmo.

Chegou assim à ponte de Diamante, na qual entrou, atravessando-a rapidamente; depois, chegando ao cáis da ilha de S. Luiz, levantou a cabeça e examinou com rápida vista os últimos andares das casas vizinhas.

Por detrás do hotel Lambert, no sexto andar de uma casa da rua S. Luiz, brilhava uma luz junto dos vidros da janela.

A casa era de modesta aparência, e parecia habitada, ou por artistas, ou honrados burgueses que, em um bairro tão retirado, como o da Ilha de S. Luiz, não costumavam velar de certo até muito tarde. ${ }^{31}$

Em muitas situações, o local de moradia dos personagens complementa a sua descrição e ressalta as características sociais. Como no caso do Conde Armando de Kergaz, que se instala próximo

31 TERRAIL, op. cit., vol. 1, p. 33. 
ao faubourg Santo Antônio para poder exercer melhor sua atividade filantrópica.

\begin{abstract}
Armando morava na rua Culture-Saint-Catherine desde que tomara posse de sua imensa fortuna. $\mathrm{O}$ isolamento daquele bairro agradava-lhe e permitia estar, ao mesmo tempo, mais perto das classes laboriosas e pobres, que beneficiava com suas esmolas misteriosas. ${ }^{32}$
\end{abstract}

No caso de Joana de Balder, futura esposa de Armando, o local de moradia reflete sua decadência econômica após a morte do pai: Joana e sua mãe não conseguem mais manter o padrão de vida que tinham enquanto o coronel estava vivo, e precisam mudar de residência para um local mais barato.

A Sra. de Balder e sua filha tinham ido morar naquele bairro, primeiro por economia, segundo para se tornarem esquecidas na sociedade rica e elegante em que tinham brilhado; porque no ano que precedeu a morte do coronel, perdera ele uma causa importante, que o deixara completamente arruinado. ${ }^{33}$

As peregrinações dos personagens pela cidade servem também para proporcionar as situações de encontro e mesmo confronto. Bastien, serviçal de Armando, reconhece o vilão Andréia ao vê-lo passar pelos Campos Elíseos. Armando impede um ataque de bandidos ao presenciar um diálogo numa de suas vigilâncias em Belleville. Os encontros no trânsito parisiense são parte fundamental da narrativa: neles os sentimentos vêm à tona, amor, amizade, cumplicidade e ódio. 
Da rua Serpent, entrou Williams na rua de Saint-Andre des Arts, subiu-a toda até a praça do mesmo nome, e dirigiu-se para o cáis.

Passou o Sena, atravessou a cidade e chegou à praça do Chatelet.

Nesse momento, uma carruagem puxada por dois cavalos desembocou na rua de S. Diniz, e o cocheiro gritou: "arreda!..." ao capitão, que um sentimento de vaga curiosidade obrigara a aproximar-se. O capitão e o trem cruzaram-se sob a luz de um candieiro da rua.

Williams, desviou-se, mas olhou para a carruagem que tinha os vidros corridos, e à luz do candieiro viu um homem que lhe fez sufocar um grito.

- Armando!... exclamou ele.

Mas a carruagem seguiu a trote largo, levando o homem a quem Williams chamara Armando, e que, sem dúvida, não teve tempo nem de ver Williams, nem de ouvir o grito que este soltou.

O capitão ficou um momento imóvel, olhando para a carruagem que se afastava na direção do cáis; depois, cruzando os braços, disse com expressão de ódio:

Estamos finalmente na presença um do outro, irmão; tu, a estulta encarnação da virtude, eu o gênio do vício, e a personificação do mal! Vais talvez suavizar algum infortúnio com o ouro que roubaste? Pois bem, agora nós, porque tenho sêde de ouro e de vingança. ${ }^{34}$

Em Rocambole a cidade oferece o cenário no qual "o vício acotovela a virtude" e onde o mal pode triunfar. Este cenário fascinou os leitores do século XIX, ansiosos e repelidos pelos mistérios que se ocultavam sob a superfície da vida da cidade, cônscios de que novas formas de projetos industriais e de reconstrução urbana ameaçavam destruir um mundo que ainda se assemelhava, se comportava e cheirava como uma reminiscência da Idade Média. ${ }^{35}$ A narrativa de Ponson du Terrail mesclava referências à Paris antiga e moderna,

34 Idem, p. 38.

35 SEIGEL, op. cit. p. 143 
porém sempre relacionando as condições de pobreza e exploração ao sofrimento do proletariado e ao aumento das atividades criminosas.

Em 1850, Paris era uma cidade agitada com problemas e possibilidades sociais, econômicas e políticas. ${ }^{36}$ Alguns a viam como uma cidade doente, varrida por tormentas políticas, separada, partida pela luta de classes afundando sob o peso de sua própria carga de decadência, corrupção, crime e cólera. Outros a viam como uma cidade de oportunidades para a ambição privada ou progresso social. Durante todo o século XIX, a preocupação com o racionalismo mecanicista e o consequente culto do dinheiro estiveram presentes. $\mathrm{O}$ crescimento da taxa de urbanização e o surgimento da cidade industrial de construção barata dramatizaram as condições urbanas que até então passavam despercebidas. Essa transformação negativa da paisagem social ocorreu contra o pensamento otimista sobre o progresso e a riqueza da civilização por meio da cidade. A cidade como símbolo ficou presa na rede psicológica de esperanças frustradas, agora simbolizada em tijolos, fuligem, imundície e crime. 37

As novas ruas e construções durante o Segundo Império começaram a destruir alguns antigos setores habitacionais e dar à cidade um aspecto diferente, mais moderno. Essa grande "expurgação da imagem urbana" fez com que bairros inteiros desaparecessem e surgissem, em seu lugar, espaços de renovação urbana, dentro da ideia de "limpar e moralizar".

Maior número de trapeiros surgiu nas cidades desde que, graças aos novos métodos industriais, os rejeitos ganharam certo valor. Trabalhavam para intermediários e representavam uma espécie de indústria caseira situada na rua. O trapeiro fascinava a sua época. Encantados, os olhares dos primeiros investigadores do pauperismo nele

36 A capital francesa foi palco de diferentes processos revolucionários em um curto período de tempo: a Revolução Francesa de 1789, a Revolução Liberal de 1830 e a Primavera dos Povos de 1848 resultaram em um cenário instável de intensas contradições.

37 SCHORSKE, op. cit., p. 61. 
se fixaram com a pergunta muda: "Onde seria alcançado o limite da miséria humana? ${ }^{38}$

Esta foi a época de grande expansão da arquitetura e da construção, marcada pela elevação dos preços de casas e demais imóveis nos bairros centrais da cidade. O Barão Haussmann. "[...] realizou sua transformação da imagem da cidade com os meios mais modestos que se possa pensar: pás, enxadas, alavancas e coisas semelhantes"39. Mas enquanto a classe média crescia e construía o seu próprio espaço habitacional, as classes exploradas continuavam apenas beneficiando-se de despesas básicas de saneamento e sendo cada vez mais afastadas das regiões nobres, encaminhadas para onde não incomodassem os mais abastados com sua presença inoportuna.

Para os planejadores de cidades, os pobres eram uma ameaça pública, suas concentrações potencialmente capazes de se desenvolver em distúrbios deveriam ser impedidas e cortadas por avenidas e bulevares, que levariam os pobres dos bairros populosos a procurar habitações em lugares menos perigosos. Esta também era a política das estradas de ferro, que fazia suas linhas passarem através destes bairros, onde os custos eram menores e os protestos negligenciáveis. Para os construtores, os pobres eram um mercado que não dava lucro, comparado aos ricos com suas lojas especializadas e distritos de comércio, e também às sólidas casas e apartamentos para a classe média. Quando os pobres não ocupavam os distritos centrais das cidades abandonadas pelas classes mais elevadas, seus lugares eram construídos por empresários especuladores ou pelos construtores dos grandes blocos de aluguel [...]. ${ }^{40}$

38 BENJAMIN, op. cit.., p. 16.

39 Idem, p. 84.

40 HOBSBAWM, op. cit., p. 224. 
As consequências da Revolução Industrial levaram a questionamentos: o problema de adaptação da cidade ao novo modo de produção e de transporte, sua nova vocação de espaço econômico, o problema social pela existência de um proletariado urbano. A solução desses problemas necessitava do auxílio do governo, da iniciativa privada e de peritos técnicos e foi efetivada por Napoleão III e Haussmann. Enquanto as obras públicas prévias serviram de paliativo para as crises econômicas e políticas, eram agora utilizadas massivamente para sustentar a prosperidade e resolver os problemas resultantes do crescimento anárquico. A rede de ruas foi ampliada, num esforço concentrado para melhorar a comunicação dentro do centro e entre o centro e os subúrbios.

As reformas administrativas estenderam os limites da capital para abarcar os subúrbios e ampliaram o número de bairros de doze para vinte, o que dobrou a área da capital. A aliança entre o Estado e a iniciativa privada promoveu o programa de trabalhos públicos que transformou a estrutura das ruas, esgotos e fornecimento de água. Por meio da criação de novas artérias, construções e parques, a fisionomia de Paris foi permanentemente alterada. ${ }^{41}$

Os historiadores ofereceram dois tipos de explicação para o programa de obras públicas do II Império. O mais frequente acentua os papéis do imperador e do prefeito e atribui a eles motivos diversos: estéticos, políticos, práticos e estratégicos. Napoleão III e Haussmann transformaram a capital, melhoraram sua comunicação, tornaram-na mais saudável e segura contra insurreições. Sem dúvida, o desejo de prover empregos não estava de todo ausente. Tão importante, no entanto, é a explicação funcionalista que enxerga a reconstrução de Paris como o necessário autoestabilizador de um sistema urbano que enfrentava problemas sem precedentes. Em toda a Europa, urbanização e industrialização forçaram as municipalidades a lidar com problemas referentes à ordem e à vida. Na primeira metade do século XIX a população parisiense dobrou, atingindo mais de um milhão de habitantes em 1851 de maneira desigual, pois os quatro 
bairros que compunham a margem direita do rio Sena continham quase um terço dos habitantes da cidade. ${ }^{42}$

Os novos bulevares permitiram ao tráfico fluir pelo centro da cidade e mover-se em linha reta, de um extremo ao outro; eliminaram as habitações miseráveis e abririam "espaços livres" em meio a camadas de escuridão e apertado congestionamento. Estimularam a expansão de negócios locais, em todos os níveis, e ajudariam a custear imensas demolições municipais, indenizações e novas construções; também criaram longos e largos corredores através dos quais as tropas de artilharia poderiam mover-se eficazmente contra futuras barricadas e insurreições populares.

As novas avenidas, imensamente amplas, meticulosamente retas, estendendo-se por quilômetros, seriam vias expressas para o

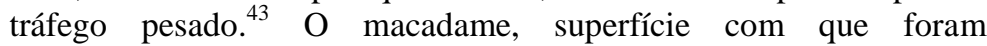
pavimentadas, era notadamente macio e fornecia perfeita tração para as patas dos cavalos. Pela primeira vez, corredores e condutores podiam lançar seus animais em plena velocidade. $\mathrm{O}$ aperfeiçoamento das condições carroçáveis não só aumentaram a velocidade do tráfego previamente existente, mas geraram um volume de tráfego mais intenso do que havia sido previsto.

No entanto, há falhas inquestionáveis nas melhoras. As habitações operárias receberam pouco incentivo de uma administração preocupada em construir para a riqueza, e não foi tomado cuidado na prevenção do aparecimento de novos bairros pobres. A diferença do leste para o oeste era acentuada e o lado direito continuou a atrair mais indústrias, comércio. Mais importante, a atenção dispensada às obras públicas na cidade contrastaram com o incontrolável crescimento dos subúrbios externos, novos centros para as populações operárias despejadas da cidade.

Os responsáveis pela demolição e reconstrução não demonstravam nenhum tipo de preocupação especial com o problema de acomodação dessa população que fora despejada. Estavam abrindo novas e amplas vias de desenvolvimento nas partes norte e leste da 
cidade; nesse meio tempo os pobres fariam, de algum modo, como sempre haviam feito.

Entre o Bosque de Bolonha e o novo boulevard que tomou o nome de Rei de Roma, há um bairro deserto que ainda não sofreu a mais breve transformação. As ruas que vão dar a ele são apenas indicadas pelos letreiros dos terrenos que estão para vender. Em baixo fica Chaillot, ao sueste Passy e ao sudoeste Auteil.

Esse bairro na época em que falamos era ocupado por uma população também sem nome como ele. Quem por ali se perde, de verão e em pleno dia, vê alguns trapeiros fumando nos seus cachimbos, mulheres cobertas de farrapos, e crianças rolando pela areia. ${ }^{44}$

A cidade tornou-se então a forma de expressão material da vida burguesa, modelada para atender aos interesses desta classe já hegemônica, que busca de forma desenfreada o desenvolvimento capitalista. De acordo com a análise de Marshall Bermann sobre as preocupações de Marx a respeito da sociedade burguesa moderna, a dinâmica do desenvolvimento capitalista representa uma nova imagem da "vida boa" 45 , como um processo de crescimento contínuo, incansável, aberto, ilimitado, esperando cicatrizar as feridas da modernidade a partir de uma modernidade mais plena e profunda. Desta forma, Marx apresenta-se excitado e entusiasmado com a burguesia e o mundo por ela criado. De forma que

[...] a burguesia proclama ser o "Partido da Ordem" na política e na cultura modernas. O imenso volume de dinheiro e energia investido em construir e o auto-

44 TERRAIL, op. cit., vol. 5, p. 121.

45 Marshal Bermann considera que Marx aproximou-se de seus inimigos burgueses e liberais, indo contra os expoentes tradicionais do comunismo, ao negar a valorização do autossacrifício, a condenação da individualidade e o sonho de um projeto onde só a luta e o esforço atingiriam o almejado fim; e principalmente ao idealizar o desenvolvimento como uma forma de vida boa. 
assumido caráter monumental de muito dessa construção - de fato, em todo o século de Marx, cada mesa e cadeira num interior burguês se assemelhava a um monumento testemunham a sinceridade e a seriedade dessa proclamação. Não obstante, a verdade é que, como Marx o vê, tudo o que a sociedade burguesa constrói é construído para ser posto abaixo. "Tudo que é sólido"das roupas sobre nossos corpos aos teares e fábricas que as tecem, aos homens e mulheres que operam as máquinas, às casas e aos bairros onde vivem os trabalhadores, às firmas e corporações que os exploram, às vilas e cidades, regiões inteiras e até mesmo as nações que as envolvem - tudo isso é feito para ser desfeito amanhã, despedaçado ou esfarrapado, pulverizado ou dissolvido, a fim de que possa ser reciclado ou substituído na semana seguinte e todo o processo possa seguir adiante, sempre adiante, talvez para sempre, sob formas cada vez mais lucrativas. ${ }^{46}$

É este mundo aristocrático que serve de cenário para a primeira parte da série. Andréia e Rocambole são mestres na arte de falsificar papéis e representar "nobres estrangeiros". Munidos de cartas de apresentações e títulos de nobreza, reforçados pelo carisma pessoal, apresentam-se sem temores em embaixadas e consulados, nos clubes exclusivos e nas residências aristocráticas. Os nobres mantêm regularmente seus palácios em Paris e suas propriedades no campo, para onde frequentemente se retiram, seja em férias ou para tratar de problemas administrativos.

Em Paris, os nobres já estavam adaptados às novas condições modernas. Frequentavam a "boa sociedade", e transitavam nos cafés, nas festas e nas "salas que eram uma espécie de terreno neutro, onde se reunia cordialmente a burguesia dinheirosa e a aristocrática. ${ }^{, 47}$ Os personagens administravam suas propriedades e levavam a vida prazerosa dos boulevards. Esta característica é constantemente ressaltada: o gosto pela Ópera dos Italianos, os passeios no Bois de 
Boulogne, o hábito de vestir-se como 'um 'leão' do boulevard, denominação então em moda, e que resumia o homem elegante, rico e ocioso daquele tempo." ${ }^{48}$

Estes jovens fidalgos mantêm a ideia da virilidade, e a preocupação com a honra regula aspectos significativos da vida e reforça os rituais de representação. O prestígio e a boa posição, aos olhos de todos, deveriam ser resguardados a qualquer preço. Dessa forma, multiplicam-se os duelos, como forma de retratação, vingança e expressão de masculinidade. Reforça-se o papel da coragem e da natureza heroica desse homem que não se deixa afrontar sem "exigir satisfações". As situações de duelo são narradas em detalhes, expressando os antigos códigos de honra e, principalmente a possibilidade do exercício de seus poderes agressivos, controlado por regras socialmente aceitas.

Se a aproximação com a burguesia permitiu certa mudança nos hábitos e códigos aristocráticos, o resultado desse contato foi mais determinante para os burgueses, ansiosos socialmente, pelo desejo de aprenderem a melhor forma de conduta. Os burgueses possuíam grandes anseios de participar da vida aristocrática. Em termos de riqueza e educação, os aristocratas e os burgueses estavam no mesmo nível, mas eram os primeiros que definiam os termos desse encontro. Os aristocratas apresentavam os gestos corporais, faciais e verbais que os burgueses não só se esforçavam em imitar, como, sobretudo, analisavam minuciosamente em busca de chaves para entender a sua própria posição insegura. ${ }^{49}$

Para Peter Gay, os burgueses estabeleceram uma série de comportamentos (a reserva, decência burguesa e mesmo a hipocrisia) diante dessa insegurança, que lhes permitiam organizar "sua reação a um mundo em constante transformação." Em meio a progressos materiais e a sucessos políticos, as classes médias estavam apreensivas com relação à condição social, às regras morais, aos conflitos familiares e às mudanças culturais. A classe burguesa não era homogênea e a desigualdade em seu interior revela as diferenças de origem e rendimentos. A maioria dos comerciantes e dos 
funcionários públicos recebiam baixos salários e lutavam para sobreviver com meios insuficientes. A possibilidade de mobilidade social servia como estímulo e fonte de esperança. A máxima das "carreiras abertas ao talento" expressava a ideia de que o mundo burguês não possuía barreiras e que possibilitava que a inteligência, a persistência e o trabalho duro fossem recompensados com a ascensão social. $^{50}$

Os personagens nobres e burgueses compartilham o cuidado com a cultura e o refinamento. Suas casas são descritas em detalhes e mostram o hábito de gastar grandes somas para manter um certo decoro em suas roupas, sua acomodação e alimentação. A moradia de elite deveria ter um salon, mobiliado com um piano, pinturas, candelabros, relógios e bibelôs, para receber visitas e mostrar que seus donos possuíam uma riqueza dedicada à vida cultivada, além das necessidades básicas. A expressão do conforto representada nos objetos de decoração, amplamente narrada por Ponson, oferece aos leitores também um pouco da vida íntima que eles mesmos gostariam de ter.

A disseminação da prosperidade gerou abundantes recursos excedentes que pediam para ser investidos não apenas em ações, mas também na caridade. $\mathrm{O}$ fato de a maioria das mulheres de classe média ser dispensada da atividade econômica as encaminhava para a filantropia. A caridade era uma prática incentivada durante o II Império, na ausência de uma política que realmente apresentasse soluções para o problema da miséria e da criminalidade. As famílias preocupavam-se principalmente com a prostituição e destinavam boas somas às doações que pudessem ajudar na reabilitação das pecadoras.

Há em Paris intermináveis meses de inverno, durante os quais o pão é caro, a lenha mais cara ainda, e que numerosas famílias vivem do insuficiente salário do seu chefe, salário que a maior parte das vezes é insignificante. O senhor foi operário, e por conseguinte conhece perfeitamente as misérias, as aflições e também

50 GAY, Peter. A educação dos sentidos: a experiência burguesa: da Rainha Vitória a Freud. São Paulo: Companhia das Letras, 1988, p. 55. 
as virtudes dos seus irmãos. Foi, pois, o senhor quem eu escolhi de preferência, para aliviar essas misérias, consolar essas aflições, e animar essas virtudes ignoradas. $\mathrm{O}$ senhor era operário, e eu torno-o mestre. Estabeleça-se no centro do arrabalde Santo Antônio, abra uma vasta oficina de marceneiro, em que possa dar trabalho a duzentos ou trezentos operários. Dê preferência, trabalho aos que forem chefes de família; para a escolha consulte sempre o seu coração. ${ }^{51}$

Rocambole, ao sair da prisão, encontra essa cidade transformada e diz a Milon: "Mas não sabes que quando estivemos na galé, e fomos companheiros, a cidade de Paris progrediu? Construíram e demoliram milhares de casas, abriram-se ruas novas, e desapareceram muitas outras." ${ }^{52} \mathrm{O}$ cenário de demolição e destruição da cidade é descrito por Ponson:

As obras estavam desertas. No meio das ruínas da casa demolida, por entre as pedras recentemente desbastadas, via-se a fogueira acesa pelo inválido, guarda das obras e do material.

Teriam posto Paris a ferro e fogo? Seria alguma horda bárbara, vinda do norte que, conquistando a rainha das cidades, deixasse a miséria e a desolação na sua passagem? [...]

Dum lado derrubavam-se as casas velhas, do outro elevavam-se as construções modernas que cresciam pouco a pouco, graças aos esforços duma legião de operários. Àquela hora porém, parecia um campo de batalha, depois de enterrados os mortos. ${ }^{53}$

51 TERRAIL, op. cit., vol. 2, p. 35 .

52 TERRAIL, op. cit., vol. 5, p. 67.

53 Idem., vol. 7, p. 338 
Para Carl Schorske, a demolição da cidade resultou para o indivíduo no afastamento dos confortos psicológicos da tradição e de qualquer sentido de participação num todo social integrado. Na visão dos novos artistas urbanos, a cidade moderna destruíra a validade de todos os credos integradores herdados. Tais crenças preservaram-se somente de forma hipócrita, como máscaras historicistas da realidade burguesa. A apreciação estética da vida moderna tornou-se, nesse contexto, apenas um tipo de compensação para a falta de âncora, de integração social ou de crença. ${ }^{54}$

Esta falta de integração social fez com que o indivíduo passasse a reivindicar a preservação da autonomia e individualidade de sua existência em face das esmagadoras forças sociais, da herança histórica, da cultura externa e da técnica de vida. As pessoas resistem a serem niveladas por mecanismos sociotecnológicos e a personalidade necessita de uma acomodação nos ajustamentos às forças externas. Neste sentido, a base psicológica do tipo metropolitano de individualidade consiste na intensificação dos estímulos nervosos, que resulta da alteração brusca e ininterrupta entre estímulos exteriores e interiores. ${ }^{55}$

O estímulo constante imposto ao indivíduo pela cidade resulta na atitude blasé, que constitui a estimulação nervosa constante, imposta pelas mudanças e o ritmo acelerado da metrópole. Uma vida em perseguição desregrada ao prazer torna uma pessoa blasé porque agita os nervos até seu ponto de mais forte reatividade por um tempo tão longo que eles finalmente cessam completamente de reagir. ${ }^{56}$ Da mesma forma, a partir da rapidez e contraditoriedade de suas mudanças, surge a incapacidade de reagir a novas sensações com a energia apropriada. A autopreservação em face da cidade grande exige um comportamento social e um estilo de vida cuja composição e ritmo formam um todo inseparável e, em muitas situações, a pessoa em nenhum lugar se sente tão solitária e perdida quanto na multidão metropolitana.

54 SCHORSKE, op. cit., p. 68.

55 SIMMEL, George. A metrópole e a vida mental. In: VELHO, Otávio (Org.). $O$ fenômeno urbano. Rio de Janeiro: Zahar Editores, 1979, p. 12.

56 SIMMEL, p. 15. 


\section{Considerações Finais}

O foco principal do romance Rocambole é o crime que assola a sociedade industrial moderna, a maneira como os indivíduos estão desprotegidos frente à ausência de valores, impotentes e impedidos de reagir às situações de perigo a que estão sujeitos. Dessa forma, Paris fornece ao "agente do mal" suas vítimas, as quais serão usadas sem escrúpulos na obtenção da meta final, seja ela o enriquecimento, a vingança, a sedução ou a simples eliminação daqueles que representem uma ameaça à concretização de seus empreendimentos criminosos.

Ponson du Terrail não tinha pretensões de criar uma obra que fosse uma "análise" de seu tempo. Ele tinha plena consciência do caráter comercial de seus escritos, e do interesse de seus leitores, chegando a afirmar que "não gostavam de se encontrar diante dos atores de seu mundo. $\mathrm{O}$ homem do povo não gosta do homem do povo, nem o marquês do marquês... São necessárias as infelicidades de uma duquesa para fazer as lavadeiras chorarem." ${ }^{57}$ Dessa forma, Ponson explora os dois mundos, e ricos e pobres se tornam vítimas do crime.

A imprensa cotidiana parisiense estava povoada de relatos de crimes e execuções, da atuação de seitas secretas, como os Thugs, que serviram de inspiração para os "estranguladores" do episódio $A$ Última Palavra de Rocambole. Sociedades secretas, assassinatos, roubos, chantagens, captação de heranças, sequestros, substituições, duelos, envenenamentos e restabelecimentos estranhos, mulheres enigmáticas, condenados milionários, criminosos redimidos, é o obscuro e fantástico tecido do romance, e é a trama de uma realidade social misteriosa. ${ }^{58}$

Em Rocambole, a representação do Bem e do Mal permite uma aproximação do ideal de civilização enquanto "regulação crescentemente diferenciada de impulsos" ${ }^{\text {"59 }}$. Os personagens representantes do bem são aqueles que melhor controlam seus

57 BELLET, op. cit., p. 209.

58 Idem., p. 203.

59 ELIAS, op. cit., p. 195. 
impulsos agressivos e sexuais; já os representantes do mal são os que não possuem o autocontrole das paixões. Porém, essa mudança nos padrões de atitude e comportamento que constitui o processo civilizador é um caminho de aprendizado, o qual se torna cada vez menos definido em decorrência das muitas possibilidades oferecidas pela existência moderna. Dessa forma, os personagens acabam sujeitos às forças do mal e oscilam em seus comportamentos.

A sociedade francesa do século XIX vivenciou a experiência da modernidade em todas as suas contradições. A esperança depositada no progresso e a possibilidade de transformação autotransformação e transformação do mundo ao redor - foi acompanhada por um turbilhão de permanente desintegração, luta, ambiguidade e angústia. ${ }^{60}$ Ao mesmo tempo, as mudanças de atitude resultantes do processo civilizador marcaram a experiência da sociedade burguesa durante todo o período. Inseguras em relação a si mesmas, as classes médias ainda não dispunham de formas de representação social e cultural próprias. As divisões internas da burguesia, a permanência do mundo aristocrático e o crescimento do proletariado resultaram na ausência de modelos a serem seguidos e dificultaram ainda mais o aprendizado de como viver e se comportar no mundo moderno.

Nobres, burgueses e trabalhadores; homens e mulheres, todos vivenciaram as transformações resultantes da modernização francesa. Os papéis sociais não estavam definidos e os personagens experimentam os incômodos dessa ausência de determinação. Os elementos da tradição ainda estavam presentes, mas não são mais os únicos reguladores do comportamento. Esta sensação de viver em dois mundos, a meio caminho entre o antigo e o novo, é responsável pelo caráter da experiência do indivíduo no século XIX.

$\mathrm{Na}$ tentativa de manter a ordem estabelecida a aristocracia procurou administrar, durante esse período, a supremacia social e cultural, bem como conservar sua concepção de mundo autoritária e hierárquica sem, contudo, distanciar-se das possibilidades oferecidas pelo avanço do capitalismo. Longe de ser homogênea, a sua unidade era cimentada com "representações e tradições coletivas, antigas, mas

60 BERMAN, op. cit., p. 15. 
dotadas de vida, pretensões sociais e culturais partilhadas e preferências políticas comuns." ${ }^{61}$ Novas ideias e práticas, trazidas pelo contato com a burguesia, eram adaptadas de maneira que seu status e tradição não fossem seriamente ameaçados.

A sociedade do Segundo Império, folhetinesca, foi marcada por estas transformações e a imprensa não deixou de registrá-las. Diariamente, eram publicadas na imprensa informações sobre a ascensão da burguesia, a decadência da nobreza, esse meio termo entre a tradição e a modernidade, bem como os relatos de crimes, trapaças, golpes e duelos. A partir da afirmação de Roger Chartier ${ }^{62}$ de que a invenção da imprensa criou uma cultura da impressão, entende-se que as práticas e relações estabelecidas durante a época moderna consolidam sociabilidades, interferem nas esferas pública e privada e transformam a cultura. Neste sentido, a análise das mudanças ocorridas no processo de modernização vivido na Paris do Segundo Império, a partir de seu registro em Rocambole, partiu da noção de que o folhetim era considerado a escola dos escritores da modernidade e permitiu uma aproximação dos modos de vida oitocentistas, bem como da experiência moderna da reforma urbana da Paris de Haussmann.

RECEBIDO EM: 03/01/2016 APROVADO EM: 04/04/2016

61 MAYER, Arno. A força da tradição: a persistência do Antigo Regime. 1848-1914. São Paulo: Companhia das Letras, 1987, p. 88.

62 CHARTIER, Roger. Textos, impressões e leituras. In: HUNT, Lynn. A nova história cultural. São Paulo: Martins Fontes, 1992. p. 236. 